\title{
Characterization of a rock avalanche deposit for risk assessment in the town of Celano (Fucino Basin, Central Italy)
}

\author{
A. Rinaldini, A. Marino, and M. Ciucci \\ Institute for Health and Safety at Work, Rome, Italy \\ Received: 15 July 2007 - Revised: 23 September 2007 - Accepted: 24 September 2007 - Published: 2 January 2008
}

\begin{abstract}
This paper describes multidisciplinary investigations carried out in the urban centre of Celano, a small town located at the northern edge of the Fucino Basin (Central Italy). The town lies upon a wide debris body that was recognized in this study as a rock avalanche deposit estimated to date to the Holocene. Geomorphologic studies and geophysical investigations led to a detailed characterization of the landslide deposit and the surrounding units. The information obtained was used to assess the vulnerability of the Celano municipal area, by evaluating the stability of the landslide body and the behaviour of its lithologies under seismic loads.
\end{abstract}

\section{Introduction}

This paper presents multidisciplinary data collected to assess the mass movement hazard conditions in the urban centre of Celano, a small town located at the northern edge of the Fucino Basin. The town lies upon a wide landslide body that is characterized by a sliding surface separating two different lithologies: the slope materials involved in the gravitational movement and the alluvial sediments at the bottom. This feature, and the mass movement kinematics, characterized by a steep run-out path with a wide spreading of the toe, indicate that the landslide is a rock avalanche. Local contributing factors were steep relief and the neotectonic activity of faults located near the landslide scarp.

\section{Geological framework}

The Fucino basin is delimited by Meso-Cenozoic limestone ridges that have been shortened, folded and thrusted toward NE by a complex sequence of compressional phases since the late Miocene. In the late Pliocene, post-orogenic extension created a basin with a half-graben structure, resulting from several depositional phases (Late Pliocene-Holocene), in a thick fluvio-lacustrine succession with thickness of about $1000 \mathrm{~m}$ (Cavinato et al., 2002).

The town of Celano is located in the northern edge of the basin and lies upon a hill formed by heterogeneous calcareous blocks derived downslope from the structure of Mt. Serra (Fig. 1) . In the lowest areas around Celano, out crops of alternating fine grained materials are found associated with depositional cycles that took place in a fluvio-lacustrine environment during the Holocene (Cavinato et al., 2002).

\section{Landslide morphology and morphometry}

The failed Celano rock mass slid from the southern slope of Mt. Serra (Fig. 2) and originated in a markedly concave failure surface within the limestones. The body consists of a typical rock avalanche deposit, i.e. a chaotic, though well delimited and internally continuous heap of fragments and blocks up to several cubic meters in size (Fig. 3).

The rock avalanche outline is characterized by a hummocky surface with the lower parts buried with fluviolacustrine materials separated by well developed calcareous transverse ridges. The rock avalance length is $1070 \mathrm{~m}$ and it has an estimated total volume of nearly 40 million $\mathrm{m}^{3}$. The landslide deposit is composed of a chaotic placement of blocks with sizes varying from a few decimeters to several cubic meters, and composed of intramicritic and oolitic limestones, embedded in calcareous breccias and joined by carbonatic cement.

Correspondence to: A. Rinaldini

(al.rinaldini@libero.it)

Published by Copernicus Publications on behalf of the European Geosciences Union. 
Table 1. Elastic modula from cross-hole prospectings. $\delta=$ terrenes bulk density; $V s=\mathrm{S}$-waves velocity; $V p=\mathrm{P}-\mathrm{waves}$ velocity; $G_{\max }=$ maximum shear modulus; $E_{Y}=$ Young's modulus; $v=$ Poisson ratio.

\begin{tabular}{ccccccc}
\hline Depth $(\mathrm{m})$ & $\delta\left(\mathrm{kg} / \mathrm{m}^{3}\right)$ & $V s(\mathrm{~m} / \mathrm{s})$ & $V p(\mathrm{~m} / \mathrm{s})$ & $G_{\max }(\mathrm{MPa})$ & $E_{Y}(\mathrm{MPa})$ & $v$ \\
\hline $8-12$ & 1800 & 472 & 1600 & 400 & 1163 & 0.45 \\
$16-18$ & 2300 & 714 & 2000 & 1173 & 3349 & 0.43 \\
$22-24$ & 2300 & 1042 & 2400 & 2496 & 6908 & 0.38 \\
$26-28$ & 2300 & 943 & 1900 & 2047 & 5471 & 0.34 \\
$30-32$ & 2300 & 980 & 2300 & 2211 & 6141 & 0.39 \\
$34-36$ & 2300 & 1042 & 2200 & 2496 & 6766 & 0.36 \\
$38-40$ & 1900 & 490 & 2000 & 457 & 1340 & 0.47 \\
\hline
\end{tabular}

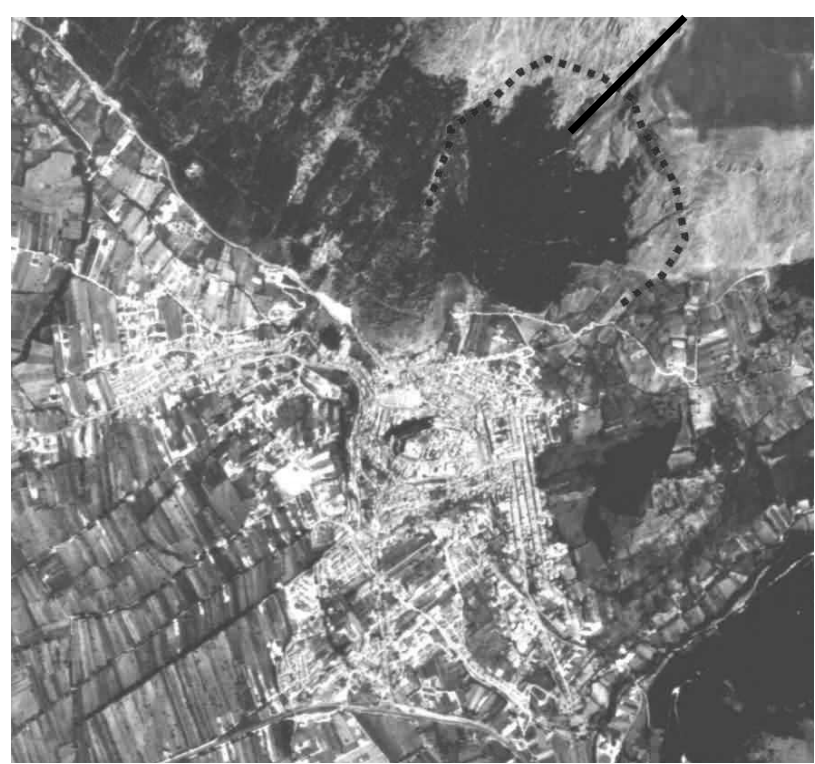

Fig. 1. Aerial photograph of Celano town: are indicated the landslide failure surface (dashed line) and the S. Vittorino fault (solid line).

\section{Geophysical investigations}

Vertical Electrical Soundings (VES) and Electrical Resistivity Tomography (ERT) surveys were used in combination to calibrate multielectrodic profiles and to evaluate the estimates of the landslide deposit depths. Additionally, the VES-ERT combination was used in cases where ERT results differed from the terrain.

\subsection{Vertical electrical soundings}

Investigations consisted of $12 \mathrm{VES}$, two of which were used for the calcareous material calibration. A Schlumberger resistivity configuration with $\mathrm{AB} / 2$ up to $250 \mathrm{~m}$ was chosen, reaching investigation depth intervals ranging from 60 to $80 \mathrm{~m}$. The VES model was developed using the theoretical

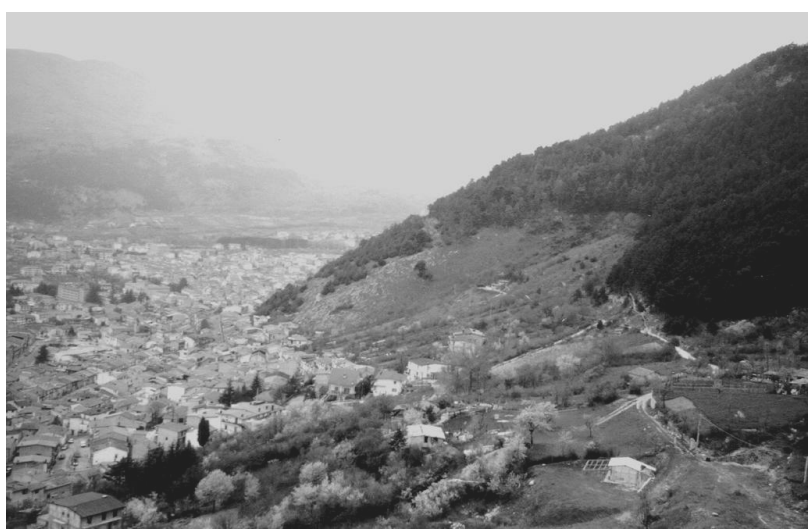

Fig. 2. Northwestern view, town of Celano, with the slope of Mt. Serra on the right.

curves of the apparent resistivity, on which was subsequently applied the iterative resolution method of the steepest descent (Koefoed, 1979). VES data indicate a presence of strata with resistivity values characteristic of calcareous lithologies within conductive zones characteristic of silty-clayey materials.

\subsection{Electrical resistivity tomography}

The Wenner, Schlumberger and radial dipole-dipole arrays were adopted for each of the four multi-electrodic surveys carried out in Celano. Measured values were then analysed using Res2Dinv software (Loke, 1998) which provides the most suitable parameters for the reconstruction of the terrain physical model. The results of each configuration were then analysed and compared with the corresponding VES models. ERT terrane models are characterized by sub-parallel strata with some lateral variation along the section and with resistivity values generally increasing with depth. 


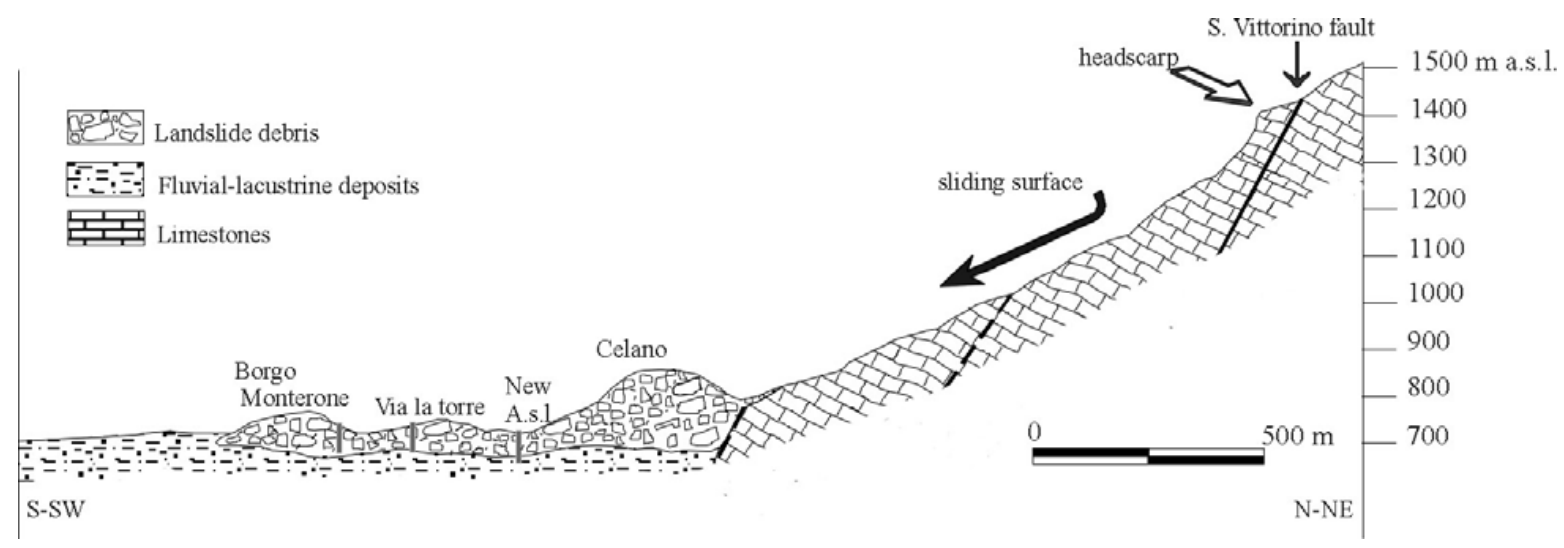

Fig. 3. Geologic section showing the path and the main geomorphic features of the Celano rock avalanche; the location of boreholes drilled at Borgo Monterone, Via la Torre and New A.s.l is also indicated.

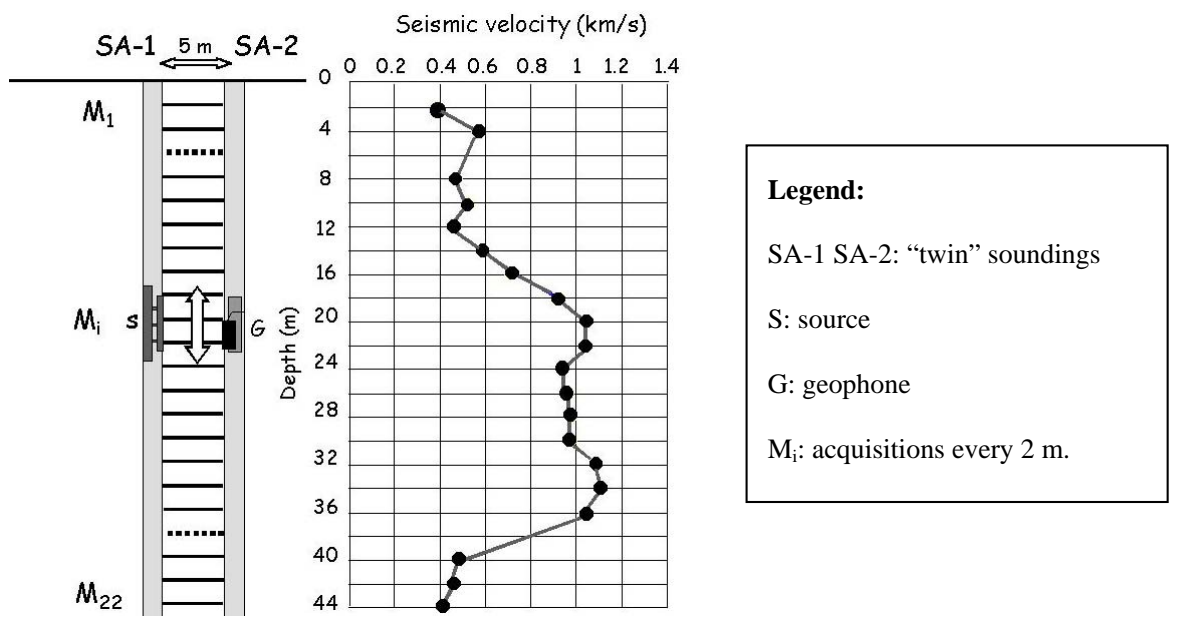

Fig. 4. Acquisition scheme from Cross-Hole waves S in New Asl site (see Fig. 3 for location).

\subsection{In situ seismic surveys}

SA-1 and SA-2 "twin" soundings, located $5 \mathrm{~m}$ apart from each other were drilled near the geoelectric survey locations. Cross-hole (C-H) investigations were carried out in these soundings. The holes hosting geophones were filled with water to enhance continuity of wave transmission between geophones and the ground.

\subsubsection{Cross-hole P-waves}

Values were elaborated considering linear ray paths of Pwaves and the investigated section was divided into $2 \times 5 \mathrm{~m}$ cells characterized by a constant velocity. An inversion algorithm with a constant damping factor of 1.6 was used for data interpretation.

\subsubsection{Cross-hole S-waves}

$\mathrm{S}$-wave measurements were acquired every $2 \mathrm{~m}$ using a tridirectional geophone, with a maximum investigation depth of $44 \mathrm{~m}$ (Fig. 4). Elastic parameters of the investigated materials were calculated from compression and shear wave values and with consideration of the soil bulk density. P and $\mathrm{S}$ cross-hole wave investigation indicated sharp variations of the materials throughout the section that was studied, as indicated in Table 1.

\section{Conclusions}

The comparison and integration of data from geoelectrical surveys and cross-hole geophysics provided a detailed framework of the rock avalanche deposit arrangement and important information related to the geomechanical characterization of the rocks in the deposit. 
Models developed from the ERT data highlighted some lateral resistivity variation of the investigated mediums only in the shallower part of the landslide body, with subhorizontal electric strata and resistivity values generally increasing with depth. The ground models obtained from geoelectrical prospecting fit with the stratigraphy identified by the drill cores.

Cross-hole geophysics provided a characterization of the lithologic succession present in Celano, with respect to the physical, mechanical and dynamic properties of the materials. Geophysical variation was shown between the investigated layers, not only between the landslide's body and the embedding terrigenous materials, but also in the calcareous debris itself. This evaluation of the dynamic behaviour of lithology contributes to a quantitative evaluation of the vulnerability of Celano.
Edited by: P. Fabian

Reviewed by: B. Malamud and M. Larsen

\section{References}

Cavinato, G. P., Carusi, C., Dall'Asta, M., Miccadei, E., and Piacentini, T.: Sedimentary and tectonic evolution of Plio-Pleistocene alluvial and lacustrine deposits of Fucino Basin (Central Italy), Sed. Geol., 148, 29-59, 2002.

Loke, M. H.: RES2DINV, Rapid 2D resistivity and IP inversion using the least-squares method, User Manual, Austin Tex, Advanced Geoscience Inc., 1998.

Koefoed, O.: Resistivity soundings measurements, Amsterdam, Elsevier, 1979. 